\title{
EVALUASI KEBIJAKAN PENINGKATAN PRODUKSI PERIKANAN BUDIDAYA
}

\author{
Yayan Hikmayani, Maharani Yulisti dan Hikmah \\ Balai Besar Penelitian Sosial Ekonomi Kelautan dan Perikanan \\ Jl. KS. Tubun Petamburan VI Jakarta 10260 \\ Telp. (021) 53650162, Fax. (021)53650159 \\ Email: yayanhikmayani@yahoo.ca
}

Diterima 22 Februari 2012 - Disetujui 23 November 2012

\begin{abstract}
ABSTRAK
Tujuan penelitian ini adalah mengevaluasi kebijakan peningkatan produksi perikanan tahun 2011. Lokasi penelitian dilakukan di Kabupaten Bogor, Jawa Barat. Metode penelitian menggunakan pendekatan kualitatif dan kuantitatif. Data yang dikumpulkan adalah data primer dan sekunder. Analisis data dilakukan secara deskriptif berdasarkan perhitungan kecenderungan produksi perikanan budidaya nasional/wilayah, analisis proyeksi produksi (forecasting) perikanan budidaya di Indonesia dan analisis Strength Weakness Opportunity Threat (SWOT). Hasil penelitian menunjukkan bahwa target produksi yang telah dicanangkan yaitu sebesar 353\% pada prinsipnya masih cukup relevan dan sangat optimis untuk tercapai. Hasil forecasting yang telah dilakukan menghasilkan nilai sebesar 335\% dan tidak terlalu jauh dengan nilai yang ditargetkan. Proyeksi patin menunjukkan peningkatan produksi sampai tahun 2014 sebesar 253\%, menunjukkan antara target produksi dan realisasi sangat jauh perbedaannya. Proyeksi produksi perikanan budidaya untuk komoditas lele, menunjukkan peningkatan produksi sampai dengan 781\% di tahun 2014, jauh lebih besar dibanding target produksi perikanan budidaya Direktorat Jenderal Perikanan Budidaya (DJPB) sebesar 450 \%. Upaya yang dapat dilakukan agar target produksi tercapai yaitu melalui optimalisasi luasan lahan yang belum diusahakan, memperbaiki sarana dan prasarana pendukung perikanan budidaya, distribusi produk perikanan yang merata di seluruh Indonesia dengan mempermudah birokrasi, meningkatkan jumlah dan kapasitas Unit Pembenihan Rakyat (UPR), mendirikan Unit Pengolahan Ikan (UPI) di lokasi sentra produksi potensial, kebijakan pemerintah mengenai harga pakan, subsidi harga input produksi terutama pakan perikanan budidaya dan kebijakan pemerintah dalam pelarangan impor ikan.
\end{abstract}

Kata Kunci: evaluasi kebijakan, perikanan budidaya, produksi

\section{Abstract: Policy Evaluation on Enhancing Aquaculture Production. By : Yayan Hikmayani, Maharani Yulisti and Hikmah.}

Research aimed at evaluating the policy to increase fisheries production has been carried out in 2011. Research location was in Bogor Regency, West Java. Qualitative and quantitative approaches were used in this research, by which primary and secondary data were collected. Data were analyzed descriptively based on calculations of the trend of national aquaculture production/territory, production projection analysis (forecasting) of aquaculture in Indonesia, and the Strength Weakness Opportunity Threat (SWOT) analysis. Result showed that the production targeted of 353\% is still relevant and optimistically can be achieved. Result from forecasting analysis of production showed the value of 335\%, by which it has no different with production targeted value. Projections showed an increase of catfish production until year 2014 amounting to $253 \%$, indicating the production and realization of the target is not balanced. Projections analysis of catfish commodities has result increased by 781\% in 2014, far greater than Directorate General of Aquaculture's production target of $450 \%$. Efforts can be made to achieve the production optional targets optimal through optimization of undeveloped land area, improving facilities and infrastructure to support aquaculture, distributing fish products equitable throughout Indonesia by simplifying the bureaucracy, 
increasing the number and capacity of the small scale hatchery, building fish processing unit in central location of potential production, intervention of government on policy making of feed prices, input prices subsidies especially on feed, and restriction on the fish imports.

\section{Keywords: policy evaluation aquaculture, production}

\section{PENDAHULUAN}

Program Kementerian Kelautan dan Perikanan (KKP) mencanangkan suatu visi yaitu Indonesia sebagai penghasil Produk Kelautan dan Perikanan Terbesar pada tahun 2015. Visi dan Misi KKP dalam Renstra 20102014, diterjemahkan lebih lanjut melalui berbagai program pembangunan kelautan dan perikanan. Target peningkatan produksi sampai dengan tahun 2015 dicanangkan sebesar $353 \%$. Peningkatan produksi ikan tersebut akan diperoleh melalui peningkatan kegiatan usaha dari sektor penangkapan dan budidaya ikan. Peningkatan produksi perikanan budidaya merupakan andalan untuk dapat mewujudkan visi tersebut.

Jika melihat target dan proyeksi produksi perikanan budidaya tahun 2008-2009, KKP optimis dalam sektor perikanan budidaya ini, mengingat sektor penangkapan yang mulai banyak hambatan mulai dari gelombang besar, over fishing, illegal fishing dan naiknya harga BBM serta rusaknya habitat terumbu karang. Komoditas prioritas perikanan budidaya yang menjadi target dari peningkatan produksi ditetapkan sebanyak 9 (sembilan) komoditas yang meliputi: udang windu, udang vaname, rumput laut, kakap, kerapu, bandeng, nila, patin dan lele. Peningkatan produksi komoditas tersebut diharapkan mampu memenuhi kebutuhan pangan ikan dan konsumsi ikan dalam negeri serta peningkatan ekspor. Perikanan budidaya harus didukung oleh penelitian yang tepat guna serta menerapkan teknologi budidaya yang tepat pula. Keoptimisan KKP perlu didukung oleh seluruh instansi yang terkait serta lapisan masyarakat. Mulai dari hal kecil, masyarakat dapat menjaga lingkungan perairan serta budaya makan ikan.
Berdasarkan data statistik Ditjen Perikanan Budidaya KKP Tahun 2010, menunjukkan bahwa realisasi produksi perikanan tahun 2009-2010 untuk seluruh komoditas meningkat. Hasil penelitian dari Balai Besar Penelitian Sosial Ekonomi Kelautan dan Perikanan (BBPSEKP), Balitbang KP tentang evaluasi sosial ekonomi pengelolaan budidaya ikan yang baik menunjukkan hasil lapangan bahwa ratarata produktivitas hasil budidaya ikan masih rendah. Capaian kinerja produksi perikanan budidaya dapat dilihat melalui ketersediaan data dan informasi yang objektif berdasarkan data-data yang akurat. Sejauh ini masih belum tersedia bahan evaluasi yang objektif tentang capaian kinerja produksi perikanan budidaya. Berdasarkan hal tersebut di atas, perlu dilakukan kajian mengenai evaluasi produksi perikanan budidaya untuk melihat status target dan realisasi produksi serta menyediakan bahan evaluasi yang objektif tentang capaian kinerja produksi perikanan budidaya.

\section{METODOLOGI}

Penelitian ini dilakukan pada bulan September 2011. Verifikasi lapang dilakukan di Kabupaten Bogor, Jawa Barat.

Penelitian ini menggunakan pendekatan kualitatif dan kuantitatif. Untuk memperoleh informasi secara komprehensif dan akurat maka penelitian ini menggunakan data primer dan sekunder. Data primer diperoleh dari verifikasi lapang terhadap sampel penelitian dengan metode survey dengan pengumpulan data terhadap pembudidaya ikan. Teknik pengumpulan data dilakukan secara desk study terhadap data 
yang tersedia. Data yang dianalisis diantaranya Data Statistik Perikanan Budidaya, Target Produksi Perikanan Budidaya 2009-2014, Petunjuk Teknis Budidaya Perikanan 9 Komoditas Unggulan, serta data hasil penelitian BBPSEKP.

FGD (Focus Group Discussion) dilakukan dalam rangka menggali informasi yang berkaitan peningkatan produksi perikanan budidaya di indonesia. FGD dilakukan dengan teknik curah pendapat dari nara sumber (expert judgment). Narasumber terdiri dari Ditjen Perikanan Budidaya, Pusat Riset Perikanan Budidaya, Perguruan Tinggi, dan Praktisi Budidaya Perikanan.

Analisis data yang digunakan meliputi analisis kuantitatif dan kualitatif. Analisis kuantitatif meliputi analisis perhitungan: (1) trend produksi perikanan budidaya nasional/wilayah; (2) analisis proyeksi produksi (forecasting) perikanan budidaya di Indonesia; dan (3) analisis SWOT untuk opsi strategi dan kebijakan peningkatan produksi serta pencatatan produksi dan permintaan. Analisis deskriptif kualitatif dilakukan atas informasi yang diperoleh dari berbagai pihak terkait evaluasi produksi perikanan budidaya di Indonesia.

Menurut Santoso (2009), forecasting adalah kegiatan yang bersifat teratur, berupaya memprediksi masa depan dengan menggunakan tidak hanya metode ilmiah, namun juga mempertimbangkan hal-hal yang bersifat kualitatif, seperti perasaan, pengalaman seseorang dan lainnya. Forecasting dapat diartikan sebagai peramalan atau prediksi. Namun karena istilah tersebut sudah sangat popular, kata forecasting akan digunakan secara bergantian dengan peramalan dan prediksi dengan maksud yang sama. Bagi seorang peramal, jangka waktu ke depan (time horizon) merupakan faktor yang paling penting yang harus diperhatikan dalam pemilihan teknik peramalan. Menurut Arsyad (2001) menjelaskan, untuk peramalan jangka pendek dan menengah, beberapa teknik peramalan kuantitatif bisa digunakan.

Analisis SWOT digunakan untuk merumuskan strategi kebijakan dalam rangka pemberdayaan masyarakat nelayan dengan mengidentifikasi berbagai faktor internal, yaitu kekuatan (strength) dan kelemahan (weakness) dengan faktor eksternal, yaitu peluang (Oppurtunity) dan ancaman (Threats). Model analisis SWOT menurut Kearns (1992) dan David (1989) dalam Salusu (1996) dapat dilihat pada Tabel 1.

Dalam menentukan strategi yang terbaik, dilakukan pemberian bobot (nilai) terhadap tiap unsur SWOT berdasarkan tingkat kepentingan dan kondisi suatu wilayah. Bobot (nilai) yang diberikan berkisar antara 1-4. Setelah masing-masing unsur SWOT diberi bobot (nilai), unsur-unsur

Tabel 1. Model Matriks Strength, Weakness, Opportunities, dan Threats (SWOT). Table 1. Matrix Model of Strength, Weakness, Opportunities, and Threats (SWOT).

\begin{tabular}{|c|c|c|}
\hline $\begin{array}{l}\text { Faktor eksternal/ } \\
\text { External Factors }\end{array}$ & Kekuatan /Strength (S) & Kelemahan /Weakness (W) \\
\hline Peluang /Oppurtunities (O) & $\begin{array}{l}\text { Strategi SO/ } \\
\text { SO Strategy }\end{array}$ & $\begin{array}{l}\text { Strategi WO/ } \\
\text { WO Strategy }\end{array}$ \\
\hline Ancaman / Threats $(T)$ & $\begin{array}{l}\text { Strategi ST/ } \\
\text { ST Strategy }\end{array}$ & $\begin{array}{l}\text { Strategi WT/ } \\
\text { WT Strategy }\end{array}$ \\
\hline
\end{tabular}


tersebut dihubungkan keterkaitannya dalam bentuk matriks untuk memperoleh beberapa alternatif strategi. Kemudian alternatifalternatif tersebut dijumlahkan bobotnya untuk menghasilkan rangking tiap-tiap strategi yang diprioritaskan untuk dilakukan (Rangkuti, 2000).

\section{STATUS TARGET DAN REALISASI PRODUKSI PERIKANAN BUDIDAYA}

Data Direktorat Jendral Perikanan Budidaya (DJPB, KKP) tahun 2011 mengenai status realisasi produksi perikanan budidaya tahun 2009-2010 menunjukkan bahwa seluruh komoditas perikanan mengalami peningkatan produksi dengan nilai rata-rata 98,5\% pada Tahun 2009 dan 116,7\% pada tahun 2010. Target sasaran produksi yang dicanangkan tersebut dapat dilihat pada Tabel 2.

Tabel 2 menunjukkan bahwa target produksi perikanan budidaya per tahun untuk seluruh komoditas unggulan ratarata mengalami peningkatan. Komoditas patin memiliki persentase terbesar dalam peningkatan produksi dibandingkan komoditas lain dengan peningkatan rata-rata $70 \%$ per tahun. Demikian pula dengan komoditas lele, rumput laut, dan kerapu memiliki target peningkatan produksi yang besar dibandingkan komoditas lainnya dengan persentase peningkatan masing-masing secara

Tabel 2. Target Sasaran Produksi Nasional Perikanan Budidaya Berdasarkan Komoditas, Tahun 2009-2014.

Table 2. Objectives Target of Aquaculture National Production based on Commodity, Years 2009-2014.

\begin{tabular}{|c|c|c|c|c|c|c|c|c|c|}
\hline \multirow{2}{*}{ No } & \multirow{2}{*}{$\begin{array}{c}\text { Rincian/ } \\
\text { Details }\end{array}$} & \multicolumn{6}{|c|}{ Jumlah Produksi (ton/tahun)/ Total Production (tonnes/year) } & \multirow{2}{*}{$\begin{array}{c}\text { Kenaikan } \\
\text { Rata-rata } \\
\text { (\%)2009-2014/ } \\
\text { Increasing } \\
\text { Average (\%) } \\
\text { 2009-2014 }\end{array}$} & \multirow{2}{*}{$\begin{array}{l}\text { Kenaikan } \\
2009 \text { ke } \\
2014(\%) / \\
\text { Increasing } \\
\text { from } 2009 \text { to } \\
2014(\%)\end{array}$} \\
\hline & & 2009 & 2010 & 2011 & 2012 & 2013 & 2014 & & \\
\hline 1 & $\begin{array}{l}\text { Rumput Laut/ } \\
\text { Seaweeds }\end{array}$ & $2,574,000$ & $2,672,800$ & 3,504 & $5,100,000$ & $7,500,000$ & $10,000,000$ & 32 & 389 \\
\hline \multirow[t]{3}{*}{2} & Catfish & 332,600 & 495,600 & 749,000 & $1,146,000$ & $1,777,000$ & $2,783,000$ & & \\
\hline & $\begin{array}{c}\text { - Ikan Patin/ } \\
\text { Pangasius }\end{array}$ & 132,600 & 225,000 & 383,000 & 651,000 & $1,107,000$ & $18,883,000$ & 70 & 1,420 \\
\hline & - Ikan Lele/ Catfish & 200,000 & 270,600 & 366,000 & 495,000 & 670,000 & 900,000 & 35 & 450 \\
\hline 3 & Ikan Nila/ Tilapia & 378,300 & 491,800 & 639,300 & 850,000 & $1,105,000$ & $1,242,900$ & 27 & 329 \\
\hline 4 & Bandeng/ Milkfish & 291,300 & 349,600 & 419,000 & 503,400 & 604,000 & 700,000 & 19 & 240 \\
\hline \multirow[t]{3}{*}{5} & Udang/ shrimp & 348,100 & 400,300 & 460,000 & 529,000 & 608,000 & 699,000 & 15 & 201 \\
\hline & $\begin{array}{l}\text {-Udang Windu/ } \\
\text { tiger shrimp }\end{array}$ & 103,450 & 109,140 & 115,720 & 128,700 & 148,500 & 188,000 & 13 & 182 \\
\hline & $\begin{array}{l}\text {-Udang Vanamei/ } \\
\text { Shrimp vannamei }\end{array}$ & 244,650 & 291,160 & 344,280 & 400,300 & 459,500 & 511,000 & 16 & 209 \\
\hline 6 & Ikan Mas/ Goldfish & 254,400 & 267,100 & 280,400 & 300,000 & 325,000 & 350,000 & 7 & 138 \\
\hline 7 & Carpfish & 38,500 & 40,300 & 42,300 & 44,400 & 46,600 & 48,000 & 5 & 127 \\
\hline 8 & $\begin{array}{l}\text { Ikan Gurame/ } \\
\text { Carpfish }\end{array}$ & 4,600 & 5,000 & 5,500 & 6,500 & 7,500 & 8,500 & 13 & 185 \\
\hline 9 & $\begin{array}{l}\text { Ikan Kerapu/ } \\
\text { Grouper }\end{array}$ & 5,300 & 7,000 & 9,000 & 11,000 & 15,000 & 20,000 & 31 & 377 \\
\hline 10 & Lainnya/ others & 553,000 & 646,700 & 738,800 & 925,400 & $1,032,700$ & $1,038,700$ & 14 & 188 \\
\hline & Jumlah/ Total & $4,780,100$ & $5,376,200$ & $3,346,804$ & $9,415,700$ & $13,020,800$ & $16,890,100$ & 29 & 353 \\
\hline
\end{tabular}

Sumber: Direktorat Jendral Perikanan Budidaya KKP (2011)/

Source: Directorate General of Aquaculture (DG of Aquaculture), Ministry of Marine Affairs and Fisheries Republic of Indonesia (2011) 
berurutan sebesar 35\%, 32\% dan 31\% per tahun. Dari sisi volume produksi, rumput laut merupakan komoditas paling tinggi produksinya dengan jumlah produksi 10 juta ton pada tahun 2014.

\section{CAPAIAN KINERJA PRODUKSI PERIKANAN BUDIDAYA}

Capaian kinerja produksi perikanan digambarkan pada realisasi produksi komoditas perikanan budidaya Tahun 2009-2010 yang dapat dilihat pada Tabel 3. Realisasi produksi tahun 2009 mencapai 4,7 juta ton dan tahun 2010 sebesar 6,2 juta ton. Realisasi produksi hasil budidaya sampai tahun 2010 mengalami peningkatan sebesar $116,77 \%$.
Namun demikian, realisasi produksi budidaya tahun 2010 masih cukup realistis karena produksinya masih lebih besar dibandingkan dengan targetnya, dimana produksinya hanya sebesar 5,3 juta ton.

Berdasarkan Tabel 3, data realisasi atau capaian produksi selama tahun 2009-2010 menunjukkan peningkatan produksi terjadi pada hampir seluruh komoditas unggulan. Peningkatan persentase produksi mencapai $13,34 \%$ sampai dengan $90,55 \%$. Secara keseluruhan menurut realisasi produksi yang telah terjadi pada tahun 2009-2010 terlihat bahwa peningkatan produksi tidak terjadi secara positif untuk seluruh komoditas.

Tabel 3. Target dan Realisasi Produksi Nasional Komoditas Perikanan Budidaya, Tahun 2009-2010.

Table 3. Target and Actual National Production of Aquaculture Commodities, Year 2009-2010.

\begin{tabular}{|c|c|c|c|c|c|c|c|c|}
\hline \multirow{3}{*}{ No } & \multirow{3}{*}{$\begin{array}{l}\text { Komoditas/ } \\
\text { Commodities }\end{array}$} & \multicolumn{2}{|c|}{ Target/Target (Ton/tonnes) } & \multicolumn{4}{|c|}{ Realisasi/Realization } & \multirow{3}{*}{$\begin{array}{l}\text { Persentase } \\
\text { perubahan / } \\
\text { Percentage } \\
\text { of changing }\end{array}$} \\
\hline & & \multirow{2}{*}{$\begin{array}{c}2009 \\
\text { Volume } \\
\text { (Ton)/ } \\
\text { Volume } \\
\text { (Tonnes) }\end{array}$} & \multirow{2}{*}{$\begin{array}{c}2010 \\
\text { Volume } \\
\text { (Ton)/ } \\
\text { Volume } \\
\text { (Tonnes) }\end{array}$} & \multicolumn{2}{|c|}{2009} & \multicolumn{2}{|c|}{2010} & \\
\hline & & & & $\begin{array}{l}\text { Volume } \\
\text { (Ton)/ } \\
\text { Volume } \\
\text { (Tonnes) }\end{array}$ & $\%$ & $\begin{array}{l}\text { Volume } \\
\text { (Ton)/ } \\
\text { Volume } \\
\text { (Tonnes) }\end{array}$ & $\%$ & \\
\hline 1 & $\begin{array}{l}\text { Rumput Laut/ } \\
\text { Seaweeds }\end{array}$ & $2,574,000$ & $2,672,800$ & $2,963,556$ & 115.13 & $3,915,016$ & 116.77 & 32.11 \\
\hline \multirow[t]{2}{*}{2} & $\begin{array}{l}\text {-Udang Windu/ } \\
\text { Tiger shrimp }\end{array}$ & & 109,140 & & & 125,523 & 115.01 & 100 \\
\hline & $\begin{array}{l}\text {-Udang } \\
\text { Vanamei/ } \\
\text { Vannamei }\end{array}$ & & 291,160 & & & 250,233 & 85.94 & 100 \\
\hline 3 & $\begin{array}{l}\text { Ikan Nila/ } \\
\text { Tilapia }\end{array}$ & 378,300 & 491,800 & 323,389 & 85.48 & 456,618 & 92.85 & 41.20 \\
\hline 4 & $\begin{array}{l}\text { Bandeng/ } \\
\text { Milkfish }\end{array}$ & 291,300 & 349,600 & 328,288 & 112.7 & 422,068 & 120.73 & 28.57 \\
\hline 5 & $\begin{array}{l}\text { Ikan Mas/ } \\
\text { Goldfish }\end{array}$ & 254,400 & 267,100 & 249,279 & 97.99 & 282,529 & 105.78 & 13.34 \\
\hline 6 & $\begin{array}{l}\text { Ikan Lele/ } \\
\text { Catfish }\end{array}$ & 200,000 & 270,600 & 144,755 & 72.38 & 242,793 & 89.72 & 67.73 \\
\hline 7 & $\begin{array}{l}\text { Ikan Patin/ } \\
\text { Pangasius }\end{array}$ & 132,600 & 225,000 & 109,685 & 82.72 & 147,888 & 65.73 & 34.83 \\
\hline 8 & $\begin{array}{l}\text { Ikan Gurame/ } \\
\text { Carpfish }\end{array}$ & 38,500 & 40,300 & 46,254 & 120.14 & 6,889 & 141.16 & (85.11) \\
\hline 9 & $\begin{array}{l}\text { Ikan Kerapu/ } \\
\text { Grouper }\end{array}$ & 5,300 & 7,000 & 8,791 & 165.87 & 10,390 & 148.43 & 18.19 \\
\hline 10 & $\begin{array}{l}\text { Ikan Kakap/ } \\
\text { Snapper }\end{array}$ & 4,600 & 5,000 & 6,400 & 139.13 & 5,723 & 114.46 & (10.58) \\
\hline 11 & Lainnya/ Others & 553,000 & 646,700 & 190,107 & 34.38 & 362,253 & 56.02 & 90.55 \\
\hline \multicolumn{2}{|c|}{$\begin{array}{l}\text { Total Produksi/ } \\
\text { Total Production }\end{array}$} & $4,780,100$ & $5,376,200$ & $4,708,564$ & 98.5 & $6,277,923$ & 116.77 & 33.33 \\
\hline
\end{tabular}

Sumber : Bahan presentasi DJPB (2010) /Source: Presentation Material, DG of Aquaculture (2010) 
Komoditas yang mengalami peningkatan produksi diantaranya rumput laut, udang windu, ikan nila, mas, lele, gurame dan ikan lainnya, sementara itu untuk jenis komoditas yang mengalami penurunan persentase ditandai dengan peningkatan yang bersifat negatif. Komoditas yang mengalami penurunan produksi diantaranya adalah komoditas gurame dan kakap dengan penurunan produksi masing-masing sebesar $85,11 \%$ dan $10,58 \%$. Penurunan komoditas gurame diindikasikan karena adanya peralihan komoditas yang dibudidayakan menjadi budidaya lele. Budidaya pembesaran gurame membutuhkan waktu produksi 1 - 2 tahun untuk dapat dikonsumsi. Sementara budidaya lele hanya membutuhkan waktu produksi maksimal 3 bulan, sementara itu permintaan lele meningkat dan menyebabkan orang tertarik untuk membudidayakan. Penurunan pada komoditas kakap diindikasikan karena biaya operasional yang sangat tinggi dan benih yang sulit didapat.

Komoditas yang realisasinya tidak dapat tercapai atau lebih rendah daripada yang ditargetkan pada tahun 2010 yaitu udang vanamei $(85,94 \%)$, nila $(92,85)$, lele $(89,72 \%)$, patin $(65,73 \%)$ dan ikan lainnya (56,02\%). Meskipun demikian, komoditas lele, nila, dan udang mengalami peningkatan produksi dibandingkan tahun 2009. Penurunan produksi beberapakomoditas tersebut diindikasikan karena mahalnya biaya pakan serta rendahnya harga jual, sehingga menyebabkan kecenderungan usaha budidaya merugi dan akhirnya tidak dipelihara lagi.

Analisis proyeksi produksi perikanan budidaya dilakukan dengan tujuan untuk memperkirakan apakah target peningkatan produksi yang sudah dicanangkan tersebut dapat terealisasi atau tidak dari tahun 20112014. Untuk kebutuhan tersebut data yang digunakan adalah data realisasi produksi selama 10 (sepuluh) tahun yatu dari tahun 2000-2010. Hasil analisis proyeksi tersebut dapat dilihat pada Tabel 4.

Tabel 4 menunjukkan bahwa proyeksi peningkatan produksi perikanan budidaya yang dapat dicapai yaitu sebesar 335\%. Nilai ini lebih kecil dibandingkan dengan target produksi dari Ditjen Perikanan Budidaya KKP yaitu sebesar 353\%. Namun demikian, perbedaan persentase ini tidak terlalu jauh berbeda karena hanya selisih $18 \%$.

Berdasarkan analisis proyeksi yang dibandingkan dengan target produksi perikanan budidaya tersebut, terdapat perbedaan yang signifikan pada komoditas patin. Hasil proyeksi menunjukkan peningkatan produksi sampai tahun 2014 sebesar $252 \%$. Nilai ini mendekati persentase realisasi produksi tahun 2009 (82\%) dan tahun 2010 (62\%). Nilai ini sangat jauh dengan target produksi perikananan budidaya DJPB dengan nilai $1.420 \%$ (Tabel 2). Sementara realisasi produksi komoditas patin 2009-2010 tidak memenuhi target, bahkan realisasi produksi tahun 2010 menurun dibanding tahun 2009. Berbanding terbalik dengan komoditas lele, dari hasil analisis proyeksi produksi perikanan budidaya meningkat sampai dengan $781 \%$ pada tahun 2014, jauh lebih besar dibanding target produksi perikanan budidaya DJPB sebesar $450 \%$.

Sebagai contoh lain, hasil analisis data target produksi per provinsi (2010-2014) dan statistik perikanan budidaya (2010) untuk komoditas ikan patin terlihat adanya inkonsistesi data. Terjadi perbedaan data produksi budidaya ikan patin 2009 antara data menurut provinsi dan data menurut jenis Budidaya. Hal ini dapat terlihat pada Tabel 5. Padahal data tahun 2009 merupakan data dasar untuk mengukur target produksi tahun 2014.

Berbagai hal yang menyebabkan belum tercapainya target produksi tersebut disebabkan berbagai faktor yang sifatnya teknis maupun non teknis. Hal yang sifatnya teknis dibeberapa lokasi sentra budidaya ikan terjadi karena masih rendahnya produktivitas lahan budidaya yang diusahakan. Dari data hasil penelitian Balai Besar Riset Sosial Ekonomi kasus di beberapa lokasi produksi ikan untuk beberapa jenis 
Tabel 4. Hasil Analisis Proyeksi (Forecasting) Produksi Perikanan Budidaya, Tahun 2011-2014. Table 4. Result of Projection Analysis (Forecasting) on Aquaculture Production Year 2011-2014.

\begin{tabular}{|c|c|c|c|c|c|c|c|}
\hline \multirow[b]{2}{*}{ No } & \multirow[b]{2}{*}{$\begin{array}{l}\text { Komoditas/ } \\
\text { Commodities }\end{array}$} & \multicolumn{4}{|c|}{ Tahun (Ton)/Year (Tonnes) } & \multirow{2}{*}{$\begin{array}{c}\text { Kenaikan } \\
\text { Rata-rata } \\
(\%)(2009- \\
2014) / \\
\text { Increasing } \\
\text { Average } \\
(\%)(2009- \\
2014) \\
\end{array}$} & \multirow{2}{*}{$\begin{array}{l}\text { Kenaikan } \\
2009 \text { ke } \\
2014(\%) / \\
\text { Increasing } \\
\text { from } 2009 \\
\text { to } 2014 \text { (\%) }\end{array}$} \\
\hline & & 2011 & 2012 & 2013 & 2014 & & \\
\hline 1 & $\begin{array}{l}\text { Rumput Laut/ } \\
\text { Seaweeds }\end{array}$ & $5,099,159$ & $6,607,671$ & $8,529,405$ & $10,977,553$ & 273 & 426 \\
\hline \multirow[t]{2}{*}{2} & $\begin{array}{l}\text {-Udang } \\
\text { Windu/ Tiger } \\
\text { shrimp }\end{array}$ & 113,251 & 102,180 & 92,190 & 83,177 & 100 & 80 \\
\hline & $\begin{array}{l}\text {-Udang } \\
\text { Vanamei/ } \\
\text { Vannamei }\end{array}$ & 190,134 & 144,468 & 109,771 & 83,407 & 64 & 34 \\
\hline 3 & $\begin{array}{l}\text { Ikan Nila/ } \\
\text { Tilapia }\end{array}$ & 590,828 & 765,015 & 991,088 & $1,284,500$ & 166 & 261 \\
\hline 4 & $\begin{array}{l}\text { Bandeng/ } \\
\text { Milkfish }\end{array}$ & 543,818 & 735,926 & $1,039,051$ & $1,517,348$ & 292 & 521 \\
\hline 5 & $\begin{array}{l}\text { Ikan Mas/ } \\
\text { Goldfish }\end{array}$ & 274,452 & 269,040 & 265,413 & 262,983 & 106 & 103 \\
\hline 6 & $\begin{array}{l}\text { Ikan Lele/ } \\
\text { Catfish }\end{array}$ & 375,794 & 595,795 & 959,703 & $1,561,651$ & 374 & 781 \\
\hline 7 & $\begin{array}{l}\text { Ikan Patin/ } \\
\text { Pangasius }\end{array}$ & 183,564 & 225,904 & 276,152 & 335,785 & 176 & 253 \\
\hline 8 & $\begin{array}{l}\text { Ikan Gurame/ } \\
\text { Carp fish }\end{array}$ & 22,978 & 25,534 & 25,941 & 26,005 & 56 & 68 \\
\hline 9 & $\begin{array}{l}\text { Ikan Kerapu/ } \\
\text { Grouper }\end{array}$ & 10,274 & 10,159 & 10,046 & 9,934 & 192 & 187 \\
\hline 10 & $\begin{array}{l}\text { Ikan Kakap/ } \\
\text { Snapper }\end{array}$ & 4,943 & 4,269 & 3,687 & 3,185 & 95 & 69 \\
\hline 11 & $\begin{array}{l}\text { Lainnya/ } \\
\text { Others }\end{array}$ & 328,328 & 297,579 & 269,711 & 244,452 & 54 & 44 \\
\hline \multicolumn{2}{|c|}{$\begin{array}{l}\text { Total Produksi/ } \\
\text { Total production }\end{array}$} & $7,737,524$ & $9,783,541$ & $12,572,157$ & $16,389,981$ & 215 & 335 \\
\hline
\end{tabular}

Sumber: Data diolah (2011)/Source: Data processed (2011)

ikan masih berada dibawah produktivitas optimalnya (Tabel 6). Produktivitas budidaya ikan lele dan nila di KJA untuk kasus di lokasi survei sudah melebihi dari produktivitas optimalnya. Produktivitas ikan lele untuk kasus di Bogor sebesar $21 \mathrm{~kg} / \mathrm{m}^{2} /$ musim tanam, sementara produktivitas optimalnya sebesar $15 \mathrm{~kg} / \mathrm{m}^{2} /$ musim (Anonymous, 2010). Apabila dikaitkan dengan realisasi produksi ikan lele dimana melebihi nilai yang ditargetkan, data ini menjadi bukti bahwa pada tahun 2009-2010 pengusahaan ikan lele oleh masyarakat sudah dilakukan cukup intensif.

Sementara itu kasus budidaya ikan nila di KJA di Jambi menunjukkan bahwa produktivitas budidaya yang dilakukan sudah melebihi dari produktivitas optimalnya. Dari sisi pembudidaya hal ini menunjukkan bahwa budidaya nila sangat menguntungkan. Penyebab meluasnya budidaya nila di KJA pada saat dilakukan survey, harga patin serta permintaan pasarnya sedang menurun sehingga pembudidaya beralih untuk membudidayakan ikan nila (BBRSEKP, 2010). 
Tabel 5. Perbedaan Data Produksi Budidaya Ikan Patin Tahun 2009 (ton). Table 5. Different Data of Pangasius Aquaculture Production Year 2009 (tonnes).

\begin{tabular}{|c|c|c|c|c|c|}
\hline \multirow[b]{2}{*}{ Uraian/Description } & \multicolumn{5}{|c|}{$\begin{array}{c}\text { Produksi ikan per Jenis Budidaya (ton)/ } \\
\text { Fish Production by Type of Aquaculture (tonnes) }\end{array}$} \\
\hline & $\begin{array}{l}\text { KJA/ } \\
\text { Floating } \\
\text { cage nets }\end{array}$ & $\begin{array}{l}\text { Sawah/ } \\
\text { Paddy } \\
\text { fields }\end{array}$ & $\begin{array}{l}\text { Keramba/ } \\
\text { Cage nets }\end{array}$ & $\begin{array}{l}\text { Kolam/ } \\
\text { Fish Ponds }\end{array}$ & $\begin{array}{l}\text { Jumlah/ } \\
\text { Amount }\end{array}$ \\
\hline $\begin{array}{l}\text { Data target sasaran produksi } \\
\text { nasional/ Data of national } \\
\text { production target }\end{array}$ & - & - & - & - & 132,600 \\
\hline $\begin{array}{l}\text { Data target sasaran produksi per } \\
\text { provinsi/ Data of production target } \\
\text { per province }\end{array}$ & - & - & - & - & 13,000 \\
\hline $\begin{array}{l}\text { Realisasi produksi ikan patin } \\
\text { berdasarkan statistik perikanan } \\
\text { budidaya per provinsi/ Realization } \\
\text { production of pangasius fish } \\
\text { base on aquaculture statistic per } \\
\text { province }\end{array}$ & 19,831 & 107 & 18,710 & 53,457 & 92,105 \\
\hline $\begin{array}{l}\text { Realisasi produksi ikan patin } \\
\text { berdasarkan statistik perikanan } \\
\text { menurut jenis budidaya/ } \\
\text { Realization production of pangasius } \\
\text { fish base on aquaculture statistic by } \\
\text { type of aquaculture }\end{array}$ & 19,859 & 106 & 19,657 & 70,064 & 109,686 \\
\hline
\end{tabular}

Sumber: Target sasaran Produksi perikanan budidaya 2010-2014 (2011) Statistik perikanan budidaya Indonesia (2010)

Source: National Aquaculture production target 2010-2014 (2011)

Statistic of Indonesian aquaculture (2010)

Tabel 6. Produktivitas Aktual dan Optimal Komoditas Unggulan Perikanan Budidaya di Beberapa Lokasi Potensial, Tahun 2010.

Table 6. Actual and Optimal Productivity of Prime Commodities of Aquaculture in Some Potential Location, Year 2010.

\begin{tabular}{|c|c|c|c|}
\hline No & $\begin{array}{l}\text { Komoditas/ } \\
\text { Commodities }\end{array}$ & $\begin{array}{c}\text { Produktivitas } \\
\left(\mathrm{kg} / \mathrm{m}^{2} / \mathrm{musim}\right. \\
\text { tanam)/ } \\
\text { Productivities } \\
\text { (kilograms } / \mathrm{m}^{2} \text { / }\end{array}$ & $\begin{array}{c}\text { Produktivitas Optimal*) } \\
\text { (hasil riset) }\left(\mathrm{kg} / \mathrm{m}^{2} /\right. \\
\text { musim tanam)/Optimal } \\
\text { Productivities (Research } \\
\text { results) (kilograms } / \mathrm{m}^{2} \text { ) } \\
\text { growing season }\end{array}$ \\
\hline 1 & $\begin{array}{l}\text { Ikan Lele di Kabupaten Bogor (Budidaya intensif)/ } \\
\text { Catfish in Bogor District (Intensive aquaculture) }\end{array}$ & 21 & 15 \\
\hline 2 & $\begin{array}{l}\text { Ikan Patin di Kabupaten Muaro Jambi/ Pangasius } \\
\text { in Muaro Jambi District }\end{array}$ & 6 & 12 \\
\hline 3 & $\begin{array}{l}\text { Ikan Nila di Kabupaten Jambi (KJA) }\left(\mathrm{Kg} / \mathrm{m}^{2} / \mathrm{thn}\right) / \\
\text { Tilapia in Jambi District (Floating Cage net) }\end{array}$ & 16 & 12 \\
\hline 4 & $\begin{array}{l}\text { Udang Windu di Kabupaten Gresik (teknologi } \\
\text { tradisional)/ Tiger Shrimp in Gresik District } \\
\text { (Traditional technology) }\end{array}$ & 0.0084 & 0.03 \\
\hline 5 & $\begin{array}{l}\text { Ikan Bandeng di Kabupaten Gresik (teknologi } \\
\text { tradisional)/ Milkfish in Gresik District (Traditional } \\
\text { technology) }\end{array}$ & 0.0626 & 0.26 \\
\hline
\end{tabular}




\section{Lanjutan Tabel 6/Continue Table 6}

\begin{tabular}{|c|c|c|c|}
\hline No & $\begin{array}{l}\text { Komoditas/ } \\
\text { Commodities }\end{array}$ & $\begin{array}{l}\text { Produktivitas } \\
\left(\mathrm{kg} / \mathrm{m}^{2} / \mathrm{musim}\right. \\
\text { tanam)/ } \\
\text { Productivities } \\
\text { (kilograms } / \mathrm{m}^{2} \text { / }\end{array}$ & $\begin{array}{l}\text { Produktivitas Optimal*) } \\
\text { (hasil riset) }\left(\mathrm{kg} / \mathrm{m}^{2} /\right. \\
\text { musim tanam)/Optimal } \\
\text { Productivities (Research } \\
\text { results) (kilograms } / \mathrm{m}^{2} \text { / } \\
\text { growing season }\end{array}$ \\
\hline 6 & $\begin{array}{l}\text { Udang Vaname di Kabupaten Lamongan } \\
\text { (Tradisional Plus)/ Vannamei in Lamongan District } \\
\text { (Traditional Plus) } \\
\text { - Tanah Tambak/ Brackish Ponds area } \\
\text { - Tanah Sawah Tambak/ Brackish water paddy } \\
\text { fields area }\end{array}$ & 0.04 & 0.06 \\
\hline 7 & $\begin{array}{l}\text { Ikan Patin di Banjarmasin (Intensif)/ Pangasius in } \\
\text { Banjarmasin (Intensive) }\end{array}$ & 1.1 & 4 \\
\hline 8 & $\begin{array}{l}\text { Rumput laut ( E. Cottonii) di Kabupaten Pangkep/ } \\
\text { Seaweeds (Eucheuma cottonii) in Pangkep District }\end{array}$ & 0.25 & 1.9 \\
\hline
\end{tabular}

Sumber: Hasil Riset BBRSEKP (2010)

*) data berdasarkan Petunjuk Teknis Budidaya Perikanan, DJPB dan hasil riset sebelumnya Source: Research Results from Research Center for Marine and Fisheries Socio Economics (2010)

*) The data base on Technical Guide of Aquaculture, DG of Aquaculture and research results

Belum optimalnya produktivitas usaha budidaya ikan beberapa komoditas lainnya disebabkan oleh banyak faktor, baik yang sifatnya faktor teknis, sosial maupun ekonomi. Dari hasil survei sosek sebelumnya, faktor yang paling berpengaruh dalam praktek budidaya ikan yang dilakukan oleh pembudidaya di beberapa lokasi dapat dilihat dari Tabel 7. Faktor-faktor yang berpengaruh tersebut perlu dicermati lebih serius karena akan berdampak pada tidak tercapainya produksi yang ditargetkan. Serangan hama penyakit yang menyerang pada ikan lele maupun ikan patin dapat mempengaruhi terhadap produksi hasil panen berkurang sekitar $80-100 \%$.

Kualitas benih yang tidak sesuai serta ketersediaannya juga harus mendapat perhatian penting. Dampak dari kualitas benih yang tidak baik berpengaruh pada bertambah lamanya waktu pemeliharaan karena ikan tidak cepat tumbuh, sehingga menjadi tidak efisien. Bertambahnya waktu pemeliharaan akan berdampak pada bertambahnya kebutuhan pakan yang harus disediakan oleh pembudidaya.
Tercapainya target produksi yang telah dibuat tergantung pada ketersediaan jumlah benih sesuai dengan yang dibutuhkan serta kualitasnya. Peningkatan kualitas benih dapat diupayakan melalui sertifikasi UPR sehingga dapat dijamin menghasilkan kualitas benih yang baik. Ketersediaan jumlah benih sesuai dengan yang dibutuhkan sangat dipengaruhi oleh ketersediaan panti-panti benih yang ada baik di sentra produksi maupun lainnya yang mampu mensuplay seluruh kebutuhan benih. Dengan asumsi jumlah produksi yang ditarget kan sampai dengan tahun 2014, maka jumlah benih yang dibutuhkan dapat diprediksi seperti pada Tabel 8.

Data ketersediaan UPR serta panti benih ikan yang ada di Indonesia serta produktivitasnya dapat digambarkan pada tabel 9. Dari data tabel 8 dan 9 menunjukkan bahwa ketersediaan benih untuk beberapa komoditas masih sangat kurang. Sebagai contoh untuk ikan lele, kebutuhan benih pada tahun 2012 sebanyak 4.950.000.000 ekor, sementara jumlah benih yang dihasilkan oleh seluruh UPR sebanyak 1.000.755.093 ekor atau baru terpenuhi sebanyak $20 \%$ dari total kebutuhan. 


\section{Tabel 7. Sintesa Faktor Dominan yang Berpengaruh dalam Praktek budidaya Ikan Berdasarkan Jenis Ikan yang dibudidayakan, Tahun 2010.}

Table 7. Synthesis of Dominant Factors Influence on Aquaculture Practices base on Fish Type, Year 2010.

\begin{tabular}{|c|c|c|c|}
\hline \multirow{2}{*}{$\begin{array}{l}\text { Jenis Budidaya/ } \\
\text { Type of Aquaculture }\end{array}$} & $\begin{array}{l}\text { Faktor Dominan/ } \\
\text { Dominant Factors }\end{array}$ & $\begin{array}{l}\text { Faktor Dominan/ } \\
\text { Dominant Factors }\end{array}$ & $\begin{array}{l}\text { Faktor Dominan/ } \\
\text { Dominant Factors }\end{array}$ \\
\hline & Teknis/ Technical & Sosial/Social & Ekonomi/Economy \\
\hline $\begin{array}{l}\text { Lele di Bogor } \\
\text { (Intensif)/ } \\
\text { Catfish in Bogor } \\
\text { (Intensive) }\end{array}$ & $\begin{array}{l}\text { Penyakit, kualitas } \\
\text { benih, kualitas } \\
\text { pakan/ Diseases, seed } \\
\text { Quality, feed quality }\end{array}$ & $\begin{array}{l}\text { Masih lemahnya } \\
\text { kelembagaan } \\
\text { permodalan/ Capital } \\
\text { institutions are still weak }\end{array}$ & $\begin{array}{l}\text { Harga benih dan harga } \\
\text { pakan yang meningkat } \\
\text { terus/ Seed and feed prices } \\
\text { are continued rising }\end{array}$ \\
\hline $\begin{array}{l}\text { Patin di Muaro } \\
\text { Jambi/Pangasius } \\
\text { in Muaro Jambi }\end{array}$ & $\begin{array}{l}\text { Penyakit, kualitas } \\
\text { benih, kualitas } \\
\text { pakan/ Diseases, seed } \\
\text { Quality, feed quality }\end{array}$ & $\begin{array}{l}\text { Masih lemahnya } \\
\text { kelembagaan } \\
\text { permodalan/ Capital } \\
\text { institutions are still weak }\end{array}$ & $\begin{array}{l}\text { Harga benih dan harga } \\
\text { pakan yang meningkat } \\
\text { terus/ Seed and feed prices } \\
\text { are continued rising }\end{array}$ \\
\hline $\begin{array}{l}\text { Nila di Jambi (KJA) } \\
\left(\mathrm{Kg} / \mathrm{m}^{2} / \mathrm{thn}\right) / \\
\text { Tilapia in Jambi } \\
\text { (Floating cage } \\
\text { nets) }\left(\mathrm{Kg} / \mathrm{m}^{2} / \text { year) }\right.\end{array}$ & $\begin{array}{l}\text { Ketersediaan benih } \\
\text { dan kualitasnya/ } \\
\text { Seed availability } \\
\text { quality }\end{array}$ & $\begin{array}{l}\text { Kelembagaan sarana } \\
\text { input produksi masih } \\
\text { lemah/ Infrastructure } \\
\text { institution of input } \\
\text { production is still weak }\end{array}$ & $\begin{array}{l}\text { Keterbatasan permodalan } \\
\text { untuk pembelian } \\
\text { pakan apabila ikan nila } \\
\text { dibudidayakan intensif/ } \\
\text { Limitations of capital for } \\
\text { feed when using intensive } \\
\text { technology aquaculture for } \\
\text { raising Nila fish }\end{array}$ \\
\hline $\begin{array}{l}\text { Udang Windu di } \\
\text { Gresik (teknologi } \\
\text { tradisional)/ } \\
\text { Tiger Shrimp in } \\
\text { Gresik (Traditional } \\
\text { technology) }\end{array}$ & $\begin{array}{l}\text { Penyakit, harga } \\
\text { pakan, harga BBM } \\
\text { untuk pompa air, } \\
\text { polusi/ Deases, price } \\
\text { of feed, price of fuel } \\
\text { for water pump, } \\
\text { pollution }\end{array}$ & $\begin{array}{l}\text { Kelembagaan sarana } \\
\text { input produksi masih } \\
\text { lemah/ Infrastructure } \\
\text { institution of input } \\
\text { production is still weak }\end{array}$ & $\begin{array}{l}\text { Keterbatasan permodalan } \\
\text { apabila menggunakan } \\
\text { teknologi budidaya semi } \\
\text { intensif atau intensif/ } \\
\text { Capital limitations when } \\
\text { using semi-intensive or } \\
\text { intensive technology of } \\
\text { aquaculture }\end{array}$ \\
\hline $\begin{array}{l}\text { Bandeng di } \\
\text { Gresik (teknologi } \\
\text { tradisional)/ } \\
\text { Milkfish in Gresik } \\
\text { (Traditional } \\
\text { technology) }\end{array}$ & $\begin{array}{l}\text { Kualitas benih, } \\
\text { kualitas lingkungan } \\
\text { tambak menurun/ } \\
\text { Seed quality, } \\
\text { environment quality } \\
\text { of brackish pond is } \\
\text { decreasing }\end{array}$ & $\begin{array}{l}\text { Lemahnya kelembagaan } \\
\text { produsen dan } \\
\text { permodalan/ Weakness } \\
\text { institutions of producers } \\
\text { and capital }\end{array}$ & Permodalan/Capital \\
\hline $\begin{array}{l}\text { Udang Vaname } \\
\text { di Lamongan } \\
\text { (tradisional } \\
\text { plus)/ Vannamei } \\
\text { in Lamongan } \\
\text { (traditional plus) }\end{array}$ & $\begin{array}{l}\text { Penyakit, kualitas } \\
\text { benih, penurunan } \\
\text { kualitas lingkungan } \\
\text { tambak/ Diseases, } \\
\text { seed quality, } \\
\text { environment quality } \\
\text { of brackish pond is } \\
\text { decreasing }\end{array}$ & $\begin{array}{l}\text { Kelembagaan penyedia } \\
\text { sarana input produksi/ } \\
\text { Infrastructure providers } \\
\text { of production inputs } \\
\text { institution }\end{array}$ & $\begin{array}{l}\text { Harga pakan tinggi, } \\
\text { permodalan/ High seed } \\
\text { price, capital }\end{array}$ \\
\hline
\end{tabular}

Sumber: Hasil penelitian tahun 2010/Source: Result of the study in 2010 
Tabel 8. Prediksi Jumlah Benih yang Harus Disediakan Oleh Unit Pembenihan Berdasarkan Target Produksi Perikanan Budidaya 2009-2014 (Ekor).

Table 8. Predicted Number of Seeds Must Provided by Seeding Units Based on Aquaculture Production 2009-2014 (Fingerling).

\begin{tabular}{|c|c|c|c|c|}
\hline \multirow{2}{*}{$\begin{array}{l}\text { Komoditas/ } \\
\text { Commodities }\end{array}$} & \multicolumn{4}{|c|}{$\begin{array}{l}\text { Kebutuhan Benih per tahun (Ekor) }{ }^{*} \text { )/ } \\
\text { Seed needed per year (Fingerling) }\end{array}$} \\
\hline & 2011 & 2012 & 2013 & 2014 \\
\hline $\begin{array}{l}\text { Rumput Laut (ton)/ } \\
\text { Seaweeds (tonnes) }\end{array}$ & 584,033 & 850,000 & $1,250,000$ & $1,666,667$ \\
\hline $\begin{array}{l}\text { Ikan Patin/ } \\
\text { Pangasius }\end{array}$ & $354,629,630$ & $602,777,778$ & $1,025,000,000$ & $1,743,518,519$ \\
\hline Ikan Lele/ Catfish & $3,660,000,000$ & $4,950,000,000$ & $6,700,000,000$ & $9,000,000,000$ \\
\hline Ikan Nila/ Tilapia & $5,327,500,000$ & $7,083,333,333$ & $9,208,333,333$ & $10,357,500,000$ \\
\hline Bandeng/ Milkfish & $1,571,642,911$ & $1,888,222,056$ & $2,265,566,392$ & $2,625,656,414$ \\
\hline Udang/Shrimps & & & & \\
\hline $\begin{array}{l}\text {-Udang Windu/ } \\
\text { Tiger shrimp }\end{array}$ & NA & NA & NA & NA \\
\hline $\begin{array}{l}\text {-Udang Vanamei/ } \\
\text { Vannamei }\end{array}$ & $27,542,400,000$ & $32,024,000,000$ & $36,760,000,000$ & $40,880,000,000$ \\
\hline Ikan Mas/ Goldfish & $73,307,190$ & $78,431,373$ & $84,967,320$ & $91,503,268$ \\
\hline $\begin{array}{l}\text { Ikan Gurame/ } \\
\text { Carpfish }\end{array}$ & $148,421,053$ & $155,789,474$ & $163,508,772$ & $168,421,053$ \\
\hline Ikan Kakap/Snapper & $14,378,333$ & $16,992,576$ & $19,606,818$ & $22,221,060$ \\
\hline $\begin{array}{l}\text { Ikan Kerapu/ } \\
\text { Grouper }\end{array}$ & $20,000,000$ & $24,444,444$ & $33,333,333$ & $44,444,444$ \\
\hline Lainnya/ Others & NA & NA & NA & NA \\
\hline
\end{tabular}

Begitu juga untuk nila dari kebutuhan benih pada tahun 2012 sebanyak 7.083.333.333 maka benih yang dihasilkan oleh UPR sebanyak 1.349.753.940 sehingga baru terpenuhi sekitar $19 \%$. Saat ini kekurangan benih masih di penuhi dari UPR yang tidak bersertifikat yang menghasilkan benih dengan kualitas yang belum tentu sesuai yang diharapkan. Hal ini yang harus menjadi perhatian bagi pemerintah untuk membenahi
UPR yang tidak bersertifikat atau menambah jumlah UPR yang bersertifikat sehingga kebutuhan benih berkualitas masih dapat dipenuhi.

Harga pakan yang meningkat terus bahkan lebih tinggi dari peningkatan harga ikan menyebabkan usaha budidaya ikan menjadi merugi. Akibatnya pembudidaya tidak mendapat keuntungan sehingga mengurangi niat berusaha.

\footnotetext{
${ }^{1}$ Budidaya Vaname Teknologi Sederhana di Tambak -Leaflet- (2006), Petunjuk Teknis Budidaya Ikan Kakap Putih (Lates calcarifer, Bloch) (2007), Petunjuk Teknis Budidaya Ikan Nila gesit di Kolam (2009), Petunjuk Teknis Budidaya Udang vaname Semi Intensif (2010), Petunjuk Teknis Budidaya Ikan Gurami di Kolam (2010), Petunjuk Teknis Budidaya Bandeng (2010), Standar Nasional Indonesia Budidaya Air Tawar (2010), Petunjuk Teknis Budidaya Ikan Kerapu di Karamba Jaring Apung (2011), Petunjuk Teknis Budidaya Rumput Laut Eucheuma spp (2011), Budidaya Ikan Kerapu di Tambak (2011), Direktorat Jenderal Perikanan Budidaya, Kementrian Kelautan dan Perikanan Jakarta
} 
Tabel 9. Data Jumlah Unit Pembenihan Rakyat (UPR) dan Pembenihan Skala Rumah Tangga (HSRT) di Indonesia (Ekor/RTP).

Table 9. Data on Small Scale Seeding Unit (UPR) and Household Scale Hatchery in Indonesia (Fish/Household).

\begin{tabular}{|c|c|c|c|c|c|}
\hline \multirow[b]{2}{*}{$\begin{array}{l}\text { Jenis Ikan/ } \\
\text { Fish Species }\end{array}$} & \multicolumn{2}{|c|}{$\begin{array}{c}\text { Hatchery Skala Rumah Tangga (HSRT)/ } \\
\text { Household Scale Hatchery }\end{array}$} & $\begin{array}{r}\text { Unit Pe } \\
\text { (UPR } \\
\text { Sertified }\end{array}$ & $\begin{array}{l}\text { benihan Rakyat } \\
\text { Bersertifikat / } \\
\text { nall scale Seeding } \\
\text { Unit }\end{array}$ & \multirow{2}{*}{$\begin{array}{l}\text { Jumlah Total } \\
\text { Benih yang } \\
\text { Diproduksi } \\
\text { (ekor/tahun)/ } \\
\text { Total Amount } \\
\text { of Production } \\
\text { (fish/year) }\end{array}$} \\
\hline & $\begin{array}{c}\text { Jumlah (RTP)/ } \\
\text { Amount } \\
\text { (Households) }\end{array}$ & $\begin{array}{c}\text { Rata-Rata Jumlah } \\
\text { benih yang } \\
\text { Dihasilkan (Ekor/ } \\
\text { UPR)/Average of } \\
\text { seed production } \\
\text { (fried/small scale } \\
\text { hatchery) }\end{array}$ & $\begin{array}{l}\text { Jumlah/ } \\
\text { Amount }\end{array}$ & $\begin{array}{l}\text { Jumlah Benih } \\
\text { yang Dihasilkan } \\
\text { (ekor/UPR)/ } \\
\text { Seed production } \\
\text { (fried/small } \\
\text { scale hatchery) }\end{array}$ & \\
\hline Mas/Carpfish & - & - & 291 & $3,031,273$ & $621,042,400$ \\
\hline Gurame/ carpfish & - & - & 301 & 483065 & $145,402,565$ \\
\hline Lele/catfish & - & - & 897 & $1,115,669$ & $1,000,755,093$ \\
\hline Nila/ Tilapia & - & - & 438 & $3,081,630$ & $1,349,753,940$ \\
\hline Patin/ Pangasius & & & 88 & $3,823,535$ & $336,471,080$ \\
\hline Bandeng/Milkfish & 26 & $4,800,000$ & - & - & $124,800,000$ \\
\hline $\begin{array}{l}\text { Udang Windu/ } \\
\text { Tiger shrimp }\end{array}$ & 38 & $34,670,056$ & - & - & $1,317,462,128$ \\
\hline $\begin{array}{l}\text { Udang Vannamei/ } \\
\text { Vannamei shrimp }\end{array}$ & 11 & 200,000 & - & - & $2,200,000$ \\
\hline Kerapu/grouper & 3 & 14,000 & - & - & 42,000 \\
\hline $\begin{array}{l}\text { Rumput Laut/ } \\
\text { Seaweeds }\end{array}$ & 34 & 54,580 & & & $1,855,720$ \\
\hline
\end{tabular}

Sumber: DJPB, KKP (2011)/Source: DG of Aquaculture, MMAF (2011)

Biaya pembelian pakan dalam usaha budidaya memerlukan sebesar $70-80 \%$ dari total biaya produksi. Dengan demikian, faktor ketersediaan modal untuk pembelian pakan serta pakan murah sangat menentukan dalam pencapaian target produksi ikan sampai tahun 2014.

Jumlah pakan yang dibutuhkan untuk budidaya ikan dan produksi ikan sesuai yang ditargetkan sampai tahun 2014 dengan asumsi pemberian pakan sebanyak $2 \%$ dari bobot tubuh dapat dilihat dari Tabel 10.

Semakin meningkatnya harga pakan akan menurunkan minat budidaya ikan. Studi kasus budidaya ikan di Kecamatan Gunung Sindur yang didominasi budidaya ikan lele. Lahan yang digunakan yaitu lahan kolam. Selama dua tahun terkahir budidaya ikan lele tersebut semakin menunjukkan penurunan. Hal yang menyebabkan yaitu semakin meningkatnya harga pakan dan tidak sesuai lagi dengan kenaikan harga ikan konsumsinya. Dari lahan yang ada sampai saat dilakukan survei hanya sekitar $40 \%$ yang masih budidya lele, sisanya telah beralih ke komoditas lain. Tahun 2009-2010 di Kabupaten Bogor terjadi penurunan luas areal budidaya untuk kolam air tenang sebanyak $44 \%$.

Penggunaan pakan buatan berakibat pada bertambahnya waktu pemeliharaan ikan dan ikan yang dipanen ukurannya lebih kecil dibandingkan dengan menggunakan pakan pabrikan. Keragaan usaha budidaya ikan untuk beberapa komoditas penting tersebut saat ini digambarkan seperti pada Tabel 11.

Dari tabel 11 tersebut menunjukkan bahwa dari sisi analisa usaha beberapa 
Tabel 10. Prediksi Kebutuhan Pakan untuk Mendukung Pencapaian Target Produksi Ikan 2011-2014.

Table 10. Prediction of Feed Needed to Support Target Achievement on Fish Production 2011-2014.

\begin{tabular}{|c|c|c|c|c|c|}
\hline \multirow[t]{2}{*}{ No } & \multirow{2}{*}{$\begin{array}{l}\text { Komoditas/ } \\
\text { commodities }\end{array}$} & \multicolumn{4}{|c|}{$\begin{array}{l}\text { Tahun (Ton)/ } \\
\text { Year (tonnes) }\end{array}$} \\
\hline & & 2011 & 2012 & 2013 & 2014 \\
\hline 1 & Rumput Laut/Seaweeds & 0 & 0 & 0 & 0 \\
\hline \multirow[t]{2}{*}{2} & $\begin{array}{l}\text {-Udang Windu/ } \\
\text { Tiger shrimp }\end{array}$ & $2,265.02$ & $2,043.6$ & $1,843.8$ & $1,663,54$ \\
\hline & $\begin{array}{l}\text {-Udang Vanamei/ } \\
\text { Vannamei shrimp }\end{array}$ & $3,802.68$ & $2,889.36$ & $2,195.42$ & $1,668.14$ \\
\hline 3 & Ikan Nila/ Tilapia & $11,816.56$ & $15,300.3$ & $19,821.76$ & 256.90 \\
\hline 4 & Bandeng/Milkfish & $10,876.36$ & $14,718.52$ & $20,781.02$ & $30,346.96$ \\
\hline 5 & Ikan Mas/ Goldfish & $5,489.04$ & $5,380.8$ & $5,308.26$ & $5,259.66$ \\
\hline 6 & Ikan Lele/ Catfish & $7,515.88$ & $11,915.9$ & $19,194.06$ & $31,233.02$ \\
\hline 7 & Ikan Patin/ Pangasius & $3,671.28$ & $4,518.08$ & $5,523.04$ & $6,715.7$ \\
\hline 8 & Ikan Gurame/ Carpfish & 459.56 & 510.68 & 518.82 & 520.1 \\
\hline 9 & Ikan Kerapu/ Grouper & 205.48 & 203.18 & 200.92 & 198.68 \\
\hline 10 & Ikan Kakap/Snapper & 98.86 & 85.38 & 73.74 & 63.7 \\
\hline 11 & Lainnya/ Others & $6,566.56$ & $5,951.58$ & $5,394.22$ & $4,889.04$ \\
\hline
\end{tabular}

Keterangan/Remarks:

*) Dikonversi berdasarkan petunjuk teknis budidaya perikanan, Ditjen Perikanan Budidaya, KKP²/

*) Converted based on technical guidelines for aquaculture, Directorate General of Aquaculture, MMAF

komoditas menunjukkan nilai $\mathrm{R} / \mathrm{C}$ lebih tinggi dari perhitungan pada saat usaha tersebut optimal. Hal ini menunjukkan bahwa usaha budidaya ikan tersebut sudah sangat layak diusahakan sehingga meningkatkan minat pembudidaya untuk membudidayakan ikan dan target peningkatan produksi ikan kemungkinan besar dapat direalisasikan.

Apabila dilihat dari BEP (Break Event Point) dari budidaya ikan yang diusahakan oleh pembudidaya saat ini menunjukkan berada pada kondisi menguntungkan karena nilai BEP jenis ikan tertentu mempunyai nilai yang lebih besar dari nilai BEP pada saat usaha budidaya dilakukan optimal.
Hal ini menunjukkan bahwa usaha budidaya untuk jenis ikan tersebut pengembalian modal akan tercapai pada harga produksi lebih rendah pada saat pengusahaan optimal.

Faktor yang tidak kalah pentingnya untuk mendukung pencapaian peningkatan produksi tersebut yaitu ketersediaan lahan yang ada untuk digunakan sebagai wadah budidaya. Prediksi jumlah lahan yang dibutuhkan untuk memproduksi ikan seperti yang ditargetkan dapat dilihat pada Tabel 12. Ketersediaan lahan panen tersebut dapat dihitung berdasarkan target produksi dan petunjuk teknis (juknis) perikanan budidaya.

${ }^{2}$ Budidaya Vaname Teknologi Sederhana di Tambak -Leaflet- (2006), Petunjuk Teknis Budidaya Ikan Kakap Putih (Lates calcarifer, Bloch) (2007), Petunjuk Teknis Budidaya Ikan Nila gesit di Kolam (2009), Petunjuk Teknis Budidaya Udang vaname Semi Intensif (2010), Petunjuk Teknis Budidaya Ikan Gurami di Kolam (2010), Petunjuk Teknis Budidaya Bandeng (2010), Standar Nasional Indonesia Budidaya Air Tawar (2010), Petunjuk Teknis Budidaya Ikan Kerapu di Karamba Jaring Apung (2011), Petunjuk Teknis Budidaya Rumput Laut Eucheuma spp (2011), Budidaya Ikan Kerapu di Tambak (2011), Direktorat Jenderal Perikanan Budidaya, Kementrian Kelautan dan Perikanan Jakarta. 
Tabel 11. Keragaan Usaha Budidaya Ikan serta Nilai Optimalnya. Table 11. Characteristic of Aquaculture Business and The Optimum Value.

\begin{tabular}{|c|c|c|c|c|}
\hline \multirow[t]{2}{*}{$\begin{array}{l}\text { Jenis Ikan Budidaya/ } \\
\text { Type of Fish }\end{array}$} & \multicolumn{2}{|c|}{$\begin{array}{c}\text { Keragaan Usaha di } \\
\text { Lapangan*)/Business } \\
\text { Characteristic on Fields }\end{array}$} & \multicolumn{2}{|c|}{$\begin{array}{c}\text { Kondisi Usaha Optimal**)/ } \\
\text { Optimum Condition of } \\
\text { Business }\end{array}$} \\
\hline & $\mathrm{R} / \mathrm{C}$ & BEP & $\mathrm{R} / \mathrm{C}$ & BEP \\
\hline $\begin{array}{l}\text { Udang Windu tradisional/ } \\
\text { Traditional Tiger Shrimp }\end{array}$ & 1.05 & & & \\
\hline $\begin{array}{l}\text { Udang vananmei semi intensif/ } \\
\text { Semi intensive Vannamei shrimp }\end{array}$ & 1.6 & & 1.5 & $24,536,3 / \mathrm{kg}$ \\
\hline $\begin{array}{l}\text { Udang vannamei teknologi sederhana/ } \\
\text { Simple technology Vannamei shrimp }\end{array}$ & & & 1.25 & $30,400 / \mathrm{kg}$ \\
\hline $\begin{array}{l}\text { Rumput laut (Euchema) metode } \\
\text { longline/ Long line method Seaweeds } \\
\text { (Eucheuma) }\end{array}$ & 1.1 & $6.771 / \mathrm{kg}$ & 2.69 & $5,066 / \mathrm{kg}$ \\
\hline $\begin{array}{l}\text { Kerapu di KJA/ } \\
\text { Grouper in Floating Cage net }\end{array}$ & & & 3.72 & $62,086.17 / \mathrm{kg}$ \\
\hline $\begin{array}{l}\text { Ikan gurame di kolam/ } \\
\text { Gouramy in Ponds }\end{array}$ & & & 1.1 & $14,894.15 / \mathrm{kg}$ \\
\hline $\begin{array}{l}\text { Nila gesit di KJA/ } \\
\text { Tilapia in Floating Cage net }\end{array}$ & 1.8 & & 1.25 & 9591.6/kg \\
\hline $\begin{array}{l}\text { Nila gesit di kolam/ } \\
\text { Tilapia in ponds }\end{array}$ & & & 1.25 & $9,586.6 / \mathrm{kg}$ \\
\hline Bandeng/Milkfish & 2.61 & & 1.86 & $5,361 / \mathrm{kg}$ \\
\hline $\begin{array}{l}\text { Lele di kolam tanah/ } \\
\text { catfish in soil ponds }\end{array}$ & 1.2 & & 1.1 & 10,455 \\
\hline $\begin{array}{l}\text { Patin di kolam/ } \\
\text { Pangasius in ponds }\end{array}$ & 1.8 & & & \\
\hline
\end{tabular}

Keterangan/Remarks:

*) Data hasil survey BBPSEKP (2010)/Data based on survey RCMFSE (2010)

**) Data dari Petunjuk Teknis DJPB, KKP³ / Data based on Technical Guidelines for Aquaculture, Directorate General of Aquaculture, MMAF

\section{STRATEGI DAN OPSI KEBIJAKAN PRODUKSI}

Capaian kinerja produksi perikanan budidaya pada tahun 2009-2010 (Tabel 12) menggambarkan kondisi yang dapat dicapai dengan menggunakan seluruh upaya atau ketersediaan faktor utama dan pendukung dalam budidaya. Faktor-faktor yang berpengaruh tersebut terutama terkait denganketersediaan input produksi dalam usaha budidaya seperti benih ikan, pakan, pupuk dan tenaga kerja, disamping ketersediaan lahan yang benar-benar diusahakan untuk budidaya ikan, faktor pendukung yang cukup berpengaruh yaitu penggunaan teknologi dalam usaha budidaya yang dilakukan.

Penetapan opsi serta rekomendasi harus didasarkan pada upaya mengurangi resiko dari faktor-faktor yang berpengaruh dalam menghambat upaya peningkatan produksi.

${ }^{3}$ Budidaya Vaname Teknologi Sederhana di Tambak -Leaflet- (2006), Petunjuk Teknis Budidaya Ikan Nila gesit di Kolam (2009), Petunjuk Teknis Budidaya Udang Vaname Semi Intensif (2010), Petunjuk Teknis Budidaya Ikan Gurami di Kolam (2010), Standar Nasional Indonesia Budidaya Air Tawar (2010), Petunjuk Teknis Budidaya Ikan Kerapu di Karamba Jaring Apung (2011), Petunjuk Teknis Budidaya Rumput Laut Eucheuma spp (2011), Direktorat Jenderal Perikanan Budidaya, Kementrian Kelautan dan Perikanan Jakarta. 
Tabel 12. Kebutuhan Lahan Budidaya Perikanan.

Table 12. Aquaculture Area Needed.

\begin{tabular}{|c|c|c|c|c|c|}
\hline \multirow{2}{*}{$\begin{array}{l}\text { Komoditas/ } \\
\text { Commodities }\end{array}$} & \multicolumn{5}{|c|}{$\begin{array}{l}\text { Kebutuhan Lahan per tahun (ha)/ } \\
\text { Area Needed for Aquaculture per year (hectare) }\end{array}$} \\
\hline & 2010 & 2011 & 2012 & 2013 & 2014 \\
\hline $\begin{array}{l}\text { Rumput Laut/ } \\
\text { Seaweeds }\end{array}$ & 89,093 & 116,807 & 170,000 & 250,000 & 333,333 \\
\hline \multicolumn{6}{|l|}{ Catfish } \\
\hline - $\quad$ Patin / Pangasius & 167 & 284 & 482 & 820 & 1,395 \\
\hline - $\quad$ Lele / Catfish & 1,804 & 2,440 & 3,300 & 4,467 & 6,000 \\
\hline Nila / Tilapia & 16,065 & 20,884 & 27,767 & 36,097 & 40,601 \\
\hline Bandeng/ Milkfish & 131,133 & 157,164 & 188,822 & 226,557 & 262,566 \\
\hline \multicolumn{6}{|l|}{ Udang/Shrimps } \\
\hline -Windu/Tiger shrimp & NA & NA & NA & NA & NA \\
\hline -Vaname / Vannamei & 465,856 & 550,848 & 640,480 & 735,200 & 817,600 \\
\hline Mas / Carpfish & 2,44 & 2,566 & 2,745 & 2,974 & 3,203 \\
\hline Gurame / Carpfish & 707 & 742 & 779 & 818 & 842 \\
\hline Kakap / Snapper & 33 & 37 & 44 & 50 & 57 \\
\hline Kerapu / Grouper & 2,222 & 2,857 & 3,492 & 4,762 & 6,349 \\
\hline Lainnya/ Others & NA & NA & NA & NA & NA \\
\hline
\end{tabular}

Keterangan/Remarks:

*) Data diolah berdasarkan Petunjuk Teknis Budidaya Perikanan, Ditjen Perikanan Budidaya, KKP/

*) Data was analyzed based on Technical Guidelines for Aquaculture, Directorate General of Aquaculture, MMAF

Analisis yang dilakukan untuk mendapatkan opsi serta rekomendasi tersebut digunakan pendekatan analisis SWOT dapat dilihat pada Tabel 13.

Dari hasil analisis SWOT tersebut diketahui bahwa opsi serta rekomendasi yang dapat diajukan untuk mencapai target produksi yaitu:

- Mengoptimalkan luasan lahan yang belum diusahakan. Upaya yang dapat dilakukan yaitu dengan mendata ulang lahan yang potensial serta dikaji berdasarkan kesesuaian komoditas yang akan dikembangkan untuk lahan-lahan tersebut.

- Memperbaiki sarana dan prasarana pendukung perikanan budidaya. Sarana dan pra sarana terutama di pertambakan serta kolam yang iddle diperlukan upaya khsusus karena tidak dapat dilakukan dan diserahkan sepenuhnya kepada masyarakat. Hal ini menyangkut pendanaan yang cukup besar untuk merehabilitasi serta menata ulang desain tambak serta kolam tersebut. Diperlukan pendataan yang valid perbaikan sarana serta pra sarana tersebut yang memerlukan rehabilitasi sehingga berproduksi optimal.

- Distribusi produk perikanan yang merata di seluruh Indonesia dengan mempermudah birokrasi. Kondisi wilayah Indonesia menjadi faktor penentu terjadinya penyebaran sentra-sentra antara penyedia input produksi serta pusat produksi berada bukan pada satu kawasan. Dengan demikian, distribusi dari satu wilayah ke wilayah lain menjadi penting. Terutama distribudi input produksi seperti benih, pakan dan pupuk ke lokasi sentra budidaya 
Tabel 13. Analisis Strength, Weakness, Opportunities, dan Threats (SWOT) terhadap Upaya Peningkatan Produksi.

Table 13. SWOT Analysis of Efforts to Increase Production.

\begin{tabular}{|c|c|c|}
\hline & Interna & Internal \\
\hline $\begin{array}{c}\text { Eksternal/ } \\
\text { External }\end{array}$ & $\begin{array}{l}\text { Kekuatan/Strength: } \\
\text { - Potensi lahan budidaya yang } \\
\text { masih luas/ The potential } \\
\text { area for aquaculture is still } \\
\text { widespread } \\
\text { - Ketersediaan sumberdaya air } \\
\text { yang memadai/ } \\
\text { The availability of water } \\
\text { resource is adequate } \\
\text { - Permintaan konsumsi ikan } \\
\text { di Indonesia masih tinggi/ } \\
\text { Fish consumption demand in } \\
\text { Indonesia is still high }\end{array}$ & $\begin{array}{l}\text { Kelemahan/weakness: } \\
\text { - } \quad \text { Benih yang unggul belum } \\
\text { mencukupi/ Insufficient of } \\
\text { superior seeds } \\
\text { - Harga pakan pabrikan } \\
\text { yang tinggi/ High prices of } \\
\text { Manufacture feed } \\
\text { - Keterbatasan ketersediaan } \\
\text { bahan baku pakan/ } \\
\text { The limited availability of } \\
\text { feed raw materials } \\
\text { - Keterbatasan teknologi/ } \\
\text { The limited technology } \\
\text { - Keterampilan pengolahan } \\
\text { yang belum dikuasai/ } \\
\text { Fish Processing skills have } \\
\text { not mastered }\end{array}$ \\
\hline $\begin{array}{l}\text { Peluang/Opportunities: } \\
\text { - Adanya kebijakan } \\
\text { penutupan larangan impor } \\
\text { ikan/ Closure policy on fish } \\
\text { imports } \\
\text { - Masih terbukanya peluang } \\
\text { pasar/ Opportunities } \\
\text { market is available } \\
\text { - Jumlah penduduk Indonesia } \\
\text { yang merupakan potensi } \\
\text { pasar dalam negeri/ } \\
\text { The population of Indonesia } \\
\text { is a domestic market } \\
\text { potential } \\
\text { Ancaman/Threaten: } \\
\text { - Biaya produksi yang masih } \\
\text { tinggi/ Highly production } \\
\text { cost } \\
\text { Harga impor ikan yang } \\
\text { masih rendah dibanding } \\
\text { produksi lokal/ Prices of } \\
\text { import fishes are cheaper } \\
\text { than local fishes production }\end{array}$ & $\begin{array}{l}\text { Strategi/Strategy: } \\
\text { - Mengoptimalkan luasan lahar } \\
\text { - } \text { Me optimize the undeveloped } \\
\text { budidaya/ To improve facilitie } \\
\text { aquaculture } \\
\text { - } \text { Distribusi produk perikanan y } \\
\text { dengan mempermudah birok } \\
\text { throughout Indonesia Equitab } \\
\text { - Meningkatkan jumlah dan kar } \\
\text { number and capacity of the Fi } \\
\text { - Mendirikan Unit Pengolahan } \\
\text { potensial/ To develop Fish Pro } \\
\text { potential fish production } \\
\text { - Mengeluarkan kebijakan pem } \\
\text { subsidi input budidaya/ To rel } \\
\text { prices subsidized farming inpu } \\
\text { Mensubsidi harga input produ } \\
\text { budidaya/ To subsidize price o } \\
\text { for aquaculture } \\
\text { Mengeluarkan kebijakan pem } \\
\text { impor ikan/ To release govern } \\
\text { imports }\end{array}$ & $\begin{array}{l}\text { yang belum diusahakan/ } \\
\text { and area } \\
\text { rana pendukung perikanan } \\
\text { and infrastructure to support } \\
\text { ng merata di seluruh Indonesia } \\
\text { asi /To distribute fisheries product } \\
\text { e within simplify the bureaucracy } \\
\text { asitas UPR / To increase the } \\
\text { h Processing Units } \\
\text { tan (UPI) di lokasi sentra produksi } \\
\text { essing Units at the center of } \\
\text { rintah mengenai harga pakan } \\
\text { ase government policy on food } \\
\text { si terutama pakan perikanan } \\
\text { production Input, especially feed } \\
\text { rintah mengenai pelarangan } \\
\text { nent policy on banning of fish }\end{array}$ \\
\hline
\end{tabular}

Sumber: Data diolah, 2011/Sources: Data proceed, 2011 
harus diupayakan ketepatan waktu serta jumlah sesuai dengan kebutuhan pada waktunya. Dengan demikian, jadwal tebar serta panen ikan pun sesuai dengan yang diharapkan

- Meningkatkan jumlah dan kapasitas UPR. Ketersediaan UPR yang menghasilkan benih berkualitas menjadi sangat penting. Oleh karenanya diperlukan upaya controling yang baik terhadap UPR-UPR yang ada sehingga kualitas benih yang mereka hasilkan tetap terjamin kualitasnya.

- Mendirikan UPI di lokasi sentra produksi potensial. Pembangunan UPI di sentra budidaya ikan menjadi penting untuk menampung kelebihan pasokan yang dihasilkan dari pembudidaya ikan.

- Kebijakan pemerintah mengenai harga pakan. Hal ini dapat dilakukan dengan memberikan subsidi pakan agar usaha budidaya ikan tersebut masih tetap menguntungkan. Subsidi pakan yang tepat sasaran membutuhkan pembuatan mekanisme serta penanggungjawab yang jelas, sehingga tidak menimbulkan ketimpangan dan keresahan diantara pelaku.

- Kebijakan pemerintah dalam pelarangan impor ikan.

\section{PENUTUP}

Berdasarkan target produksi DJPB, komoditas patin memiliki persentase terbesar dalam peningkatan produksi dibandingkan komoditas lain dengan peningkatan rata-rata $70 \%$ per tahun. Kemudian, hasil proyeksi (forecasting) peningkatan produksi perikanan budidaya sebesar 335\% (< target 353\%), namun perbedaan persentasenya tidak terlalu jauh berbeda

Berdasarkan proyeksi peningkatan produksi per komoditas, proyeksi patin menunjukkan peningkatan produksi sampai tahun 2014 sebesar 253\% Sementara realisasi produksi komoditas patin 20092010 tidak memenuhi target, bahkan realisasi produksi tahun 2010 menurun dibanding tahun 2009. Jadi antara target produksi dan realisasi sangat berbeda jauh. Untuk komoditas lele, dari hasil analisis proyeksi produksi perikanan budidaya meningkat sampai dengan $781 \%$ pada tahun 2014, jauh lebih besar dibanding target produksi perikanan budidaya DJPB sebesar $450 \%$.

Adanya inkonsistesi pencatatan data sehingga produksi perikanan budidaya belum dapat menggambarkan keterwakilan luasan lahan yang digunakan untuk budidaya. Hal ini disebabkan tidak tersedianya data produksi berdasarkan luas lahan baku dan luas lahan panen perikanan budidaya per komoditas.

Tiga strategi utama dalam peningkatan produksi, yang diperlukan adalah (1) mengoptimalkan luasan lahan yang belum diusahakan; (2) memperbaiki sarana dan prasarana pendukung perikanan budidaya; (3) distribusi produk perikanan yang merata diseluruh wilayah Indonesia dengan mempermudah birokrasi.

Kegiatan utama yang direkomendasikan adalah mendata ulang lahan yang potensial dan dikaji berdasarkan kesesuaian komoditas. Terkait dengan sarana dan prasarana, peningkatan jumlah dan kapasitas UPR diperlukan untuk menjamin kualitas benih yang dihasilkan. Kemudian, mendirikan UPI di lokasi produksi potensial, subsidi harga pakan (input produksi) dan pelarangan impor ikan.

\section{DAFTAR PUSTAKA}

Arsyad, L. 2001. Peramalan Bisnis. BPFE Yogyakarta,

Balai Besar Riset Sosial Ekonomi Kelautan dan Perikanan. 2010. Evaluasi Sosial Ekonomi Pengelolaan Budidaya Perikanan yang Baik. Laporan Teknis. Balai Besar Riset Sosial Ekonomi Kelautan dan Perikanan, Balitbang KP, KKP. Jakarta. 
2010. Pengembangan Model Minapolitan Berbasis Budidaya. Laporan Teknis. Balai Besar Riset Sosial Ekonomi Kelautan dan Perikanan, Balitbang KP, KKP. Jakarta.

. 2011. Pemetaan Model Minapolitan berbasis Budidaya. Laporan Tengah Tahun. Balai Besar Riset Sosial Ekonomi Kelautan dan Perikanan, Balitbang KP, KKP. Jakarta.

Direktorat Jenderal Perikanan Budidaya. 2006. Budidaya Vaname Teknologi Sederhana di Tambak. Leaflet. Direktorat Jenderal Perikanan Budidaya, Kementrian Kelautan dan Perikanan. Jakarta.

. 2007. Petunjuk Teknis Budidaya Ikan Kakap Putih (Lates calcarifer, Bloch). Direktorat Jenderal Perikanan Budidaya, Kementrian Kelautan dan Perikanan. Jakarta.

. 2009. Petunjuk Teknis Budidaya Ikan Nila Gesit di Kolam. Direktorat Jenderal Perikanan Budidaya, Kementrian Kelautan dan Perikanan. Jakarta.

. 2010a. Statistik Perikanan Budidaya Indonesia 2009. Direktorat Jenderal Perikanan Budidaya, Kementrian Kelautan dan Perikanan.Jakarta.

. 2010b. Petunjuk Teknis Budidaya Udang Vaname Semi Intensif. Direktorat Jenderal Perikanan Budidaya, Kementrian Kelautan dan Perikanan. Jakarta.

2010c. Petunjuk Teknis Budidaya Ikan Gurami di Kolam. Direktorat Jenderal Perikanan Budidaya, Kementrian Kelautan dan Perikanan Jakarta.

. 2010d. Petunjuk Teknis Budidaya Bandeng. Direktorat Jenderal Perikanan Budidaya, Kementrian Kelautan dan Perikanan. Jakarta. 2010f. Standar Nasional Indonesia Budidaya Air Tawar. Direktorat Jenderal Perikanan Budidaya, Kementrian Kelautan dan Perikanan.Jakarta.

. 2011a. Petunjuk Teknis Budidaya Ikan Kerapu di Karamba Jaring Apung. Direktorat Jenderal Perikanan Budidaya, Kementrian Kelautan dan Perikanan Jakarta . 2011b. Petunjuk Teknis Budidaya Rumput Laut Eucheuma spp. Direktorat Jenderal Perikanan Budidaya, Kementrian Kelautan dan Perikanan Jakarta . 2011c. Budidaya Ikan Kerapu di Tambak. Leaflet. Direktorat Jenderal Perikanan Budidaya, Kementrian Kelautan dan Perikanan. Jakarta.

. 2011d. Target Sasaran Produksi Perikanan Budidaya Tahun 2010-2014 Menurut Propinsi dan Kabupaten/Kota. Direktorat Jenderal Perikanan Budidaya, Kementrian Kelautan dan Perikanan. Jakarta.

Rangkuti, F., 2000. Analisis SWOT Teknik Membedah Kasus Bisnis. Reorientasi Konsep Perencanaan Strategis Untuk Menghadapi Abad 21. PT. Gramedia Pustaka Utama. Jakarta.

Salusu, J. 1996. Pengambilan Keputusan Stratejik Untuk Organisasi Publik dan Organisasi Nonprofit. PT. Grasindo Sarundajang. Jakarta.

Santoso, S. 2009. Business Forecasting Metode Peramalan Bisnis Masa Kini dengan MINITAB dan SPSS. Elex Media Komputindo. Jakarta 